\title{
Ethnoveterinary practice used for treating ruminant diseases in Ilara-mokin, Ondo State
}

\author{
A. A. Bada*, Adewole, S. O. and Agbowuro G. O. \\ Department of Biological Sciences, Elizade University, Ilara-mokin, Ondo State, Nigeria. \\ ${ }^{*}$ Corresponding author. Email: glorynew.20@gmail.com
}

Copyright (@ 2020 Bada et al. This article remains permanently open access under the terms of the Creative Commons Attribution License 4.0, which permits unrestricted use, distribution, and reproduction in any medium, provided the original work is properly cited.

Received 30th May, 2020; Accepted 7th December, 2020

\begin{abstract}
The study investigated ethno-veterinary practice being used in treating small ruminants' diseases in Ilaramokin area of Ondo State. Structured questionnaires were used in the study area to collect primary data. Twenty-one people were randomly selected from different areas of llara-mokin which included Golf community, central market, central health centre, Iloro, petrol station and Baale central and Abbattoir. Different medicinal plants which include Ocimum gratissimum, Crested Cockscomb, Chromolaena odorata, Elaeis guinensis, Momordica charantia, Vernonia amygdalina, Nicotiana tabacum and Zingiber officinale were identified to treat ruminant diseases. The diseases were categorized based on environmental or microbial diseases. Pest identified in the study area was mite that caused mange. Indigenous knowledge was been practiced in the village and there is need for conservation of the specie of ruminant that is going into extinction and medicinal plants used within the town.
\end{abstract}

Keyword: Ethno-veterinary practice, indigenous knowledge, medicinal plants, pest.

\section{INTRODUCTION}

Ethno-veterinary practice is the use of local medicine to treat ruminant diseases like lice, diarrhea, cough, mange and so on (Adeola et al., 2014). The ethnoveterinary practice has a lot of benefits which include, socioeconomic, cultural to the fauna. The ethnoveterinary practice is readily available to rural dwellers (McGaw et al., 2007), cheap, and serve as alternative medicine (Lawal et al., 2010) to orthodox medicine. Veterinary consultations are most needed when there were chronic diseases (Osho and Fasina, 2013) that cannot be cured by local medicine.

Several studies have studied ethno-veterinary practice in Ekiti State using palm oil to treat mange and use of medicinal plants to treat various ruminant diseases (Kolawole et al., 2000; Adeola et al., 2014) and in Ondostate (Osho and Fasina, 2013; Obata and Aigbokhan, 2012).

Examples of ethno-veterinary practice used in Ekiti state include palm oil, medicinal plants, palm kernel oil, kerosene, ash and so on (Adeola et al., 2014). In kenya, Maasai and Ethiopia, indigenous knowledge has been practiced to treat ruminant diseases (Jacob et al. 2004). In Bangladesha, several diseases of cattle occur like helminthiasis, lice, cough, foot and mouth and diarrhea which were treated by folk medicinal practitioners (Rahmatullah et al., 2000).

The parasitic diseases affecting the ruminant (like cattle, goat and sheep) in rural areas are tick, lice, foot and mouth diseases, helminthiasis, trypanosomiasis, anaplasmosis, theileriosis (Rahmatullah et al., 2000). Villages at each place can have a particular disease affecting their animals (Kolawole, 2007).

There is need for conservation of biodiversity (fauna and flora) in most villages of Nigeria (Khan et al., 2019). But studies have not shown ethno-veterinary practice that is practiced in llara-mokin (Ifedore local Government, Ondo State). This study therefore investigates ethno-veterinary practice that is practiced in llara-mokin, to be able to make it known to all rural dwellers that are not practicing it.

\section{MATERIALS AND METHOD}

Twenty-one people from different areas of the town were randomly selected. The survey areas for the goat were 
Golf community, central market, central health, lloro and Abbattoir area in Ilara-mokin. While the survey areas for the sheep were central market area, central health center, petrol station and Baale central area were purposely selected from different areas of llara-mokin. The survey was carried out during wet and dry season through August 2018 to February 2020. The samples were almost evenly distributed in each area.

The questionnaire was used to collect data, which contained: socioeconomic characteristics of the respondents (i.e sex, age, educational status, religion and occupation of the respondents), type of ruminants in the area, the medicinal plants used to treat the various diseases, the indigenous knowledge employed in the study area. The management practices within the town were considered, which includes housing and type of feeding.

The data were subjected to descriptive analysis in frequency and in percentages with 2016 Microsoft Excel.

\section{RESULTS}

The socioeconomic characteristics of respondents are shown in Table 1. The age of highest respondent ranged between 51 to $65(42.86 \%)$ years which could indicate their long experience in using ethnoveterinary practice. Respondents with highest percentage had no formal education $(71.43 \%)$. The highest respondents $47.62 \%$ were divorced followed by widow $42.86 \%$. Females $(80.95 \%)$ were more engaged in practicing of ethnoveterinary than males. All respondents were Christians of which $66.67 \%$ were practiced traders.

Eight medicinal plants belonging to six different families were identified in this study (Table 2). According to the questionnaire collected, leaves and fruits of plants were used to treat small ruminants. Table 3 showed medicinal value of botanicals. Eleven different botanicals were identified to be used to treat ruminant diseases like mange, diarrhea, worm, mouth sores. Table 4 showed indigenous knowledge used in treating ruminant diseases in the study area.

\section{DISCUSSION}

The socioeconomic characteristics were similar to that obtained by Adeola et al. (2014) except for age and marital status. This could be due to fact that older women were more involved in llara-mokin compared to the ones in Ekiti state. Eight species of medicinal plants belonging to eight different families were identified in llara-mokin (Adeola et al., 2014; Lawal et al., 2010). The new botanical discovered in llara- mokin was crested cockscomb. This could be due to actual geographical location that favours this type of botanical.

The medicinal values of the botanical were the same to
Table 1. Socioeconomic characteristics of respondents.

\begin{tabular}{|c|c|c|}
\hline $\begin{array}{l}\text { Socioeconomic } \\
\text { characteristics }\end{array}$ & Frequency & Percentage (\%) \\
\hline \multicolumn{3}{|l|}{ Age } \\
\hline$\leq 20$ & 0 & 0 \\
\hline $21-35$ & 1 & 4.76 \\
\hline $36-50$ & 6 & 28.59 \\
\hline $51-65$ & 9 & 42.86 \\
\hline$\geq 66$ & 5 & 23.81 \\
\hline Total & 21 & $100 \%$ \\
\hline \multicolumn{3}{|l|}{ Sex } \\
\hline Male & 4 & 19.05 \\
\hline Female & 17 & 80.95 \\
\hline Total & 21 & $100 \%$ \\
\hline \multicolumn{3}{|l|}{ Marital status } \\
\hline Single & 2 & 9.52 \\
\hline Married & 0 & 0 \\
\hline Widow & 9 & 42.86 \\
\hline Divorced & 10 & 47.62 \\
\hline Total & 21 & $100 \%$ \\
\hline \multicolumn{3}{|l|}{ Educational status } \\
\hline No formal education & 15 & 71.43 \\
\hline 1-6 (Primary education & 2 & 9.52 \\
\hline 7-12 (Secondary education) & 2 & 9.52 \\
\hline 13-18 (Tertiary education) & 2 & 9.52 \\
\hline Total & 21 & $100 \%$ \\
\hline \multicolumn{3}{|l|}{ Religion } \\
\hline Christianity & 21 & 100 \\
\hline Islamic & 0 & 0 \\
\hline Total & 21 & $100 \%$ \\
\hline \multicolumn{3}{|l|}{ Occupation } \\
\hline Trading & 14 & 66.67 \\
\hline Sewing & 0 & 0 \\
\hline Professional teaching & 1 & 4.76 \\
\hline Farming & 6 & 28.57 \\
\hline Total & 21 & $100 \%$ \\
\hline
\end{tabular}

Ekiti State (Adeola et al., 2014) but the only different was that new botanicals (Garlic, ginger) were found in Ilaramokin to treat worm. The use of the botanicals in the town is diminishing because they are switching to modern medicine to treat ruminant diseases.

Diarrhea and mange were the most diseases and pest affecting the ruminant in the area (Adeola et al., 2014; Kolawole et al., 2007).

Indigenous knowledge can be applied to treat ruminant 
Table 2. Identification of botanical used ruminant (goat and sheep).

\begin{tabular}{llll}
\hline Botanical Species & Family name & Vernacular name & Parts used \\
\hline Ocimum gratissimum & Lamiaceae & Efinrin nla & Leaves \\
Crested Cockscomb (Celosia agentea var) & Amaranthaceae & Ogimogi & Leaves \\
Chromolaena odorata & Asteraceae & Akintola & Leaves, fruit \\
Elaeis guinensis & Portulaceae & Ope & Leaves \\
Momordica charantia & Curcubitaceae & Ejinrin & Leaves \\
Vernonia amygdalina & Asteraceae & ewuro & Leaves \\
Nicotiana tabacum & & taba & Leaves \\
Zingiber officinale & Zingiberaceae & ginger & Fruit \\
\hline
\end{tabular}

Table 3. Medicinal value of botanical used for goat and sheep.

\begin{tabular}{ll}
\hline Botanical & Folk Medicinal Value \\
\hline Ocimum gratissimum & For curing diarrhea \\
Allium sativum & For curing worm \\
Crested cockscomb & For curing diarrhea \\
Agbo & For curing diarrhea \\
Chromolaena odorata & For curing mouth sores \\
Ealeis guinensis & For curing mange \\
Epaijebu & For curing diarrhea \\
Palm kernel oil & For curing worms \\
Momordica charantia & For curing diarrhea \\
Vernonia amygdalina & For curing mange, diarrhea \\
Nicotiana tabacum & For curing mange \\
Zingiber officinale & For curing worms \\
Atale & For curing worm \\
\hline
\end{tabular}

Table 4. Indigenous knowledge for goat and sheep.

\begin{tabular}{|c|c|c|}
\hline Indigenous technical knowledge & Diagnosis (English) & Diagnosis (Yoruba) \\
\hline \multicolumn{3}{|l|}{ Pest } \\
\hline Whitish scale on the body & Mange & Elewu \\
\hline \multicolumn{3}{|l|}{ Microbial disease } \\
\hline Persistent watery stooling & Diarrhea & Igbe-guru \\
\hline Sores around the mouth/blisters around the mouth & Sores in the mouth & Egbo-enu \\
\hline Bloody stool & Hematochezia & Eje inu igbe \\
\hline Passing out worms & Worms & Aran \\
\hline \multicolumn{3}{|l|}{ Environmental diseases } \\
\hline Mucus in the eye & PPR & \\
\hline Lost one eye & Blindness & \\
\hline Catarrh & Catarrh & Oju fifo \\
\hline Cough & Cough & lko \\
\hline Foot and mouth disease & Foot and mouth & Ese and Enu \\
\hline Foot and rot disease & Foot and rot & Ese bibaje \\
\hline Bloat & Bloat & Iku wiwu \\
\hline
\end{tabular}

diseases in llara-mokin as compared to that of Adeola et al. (2014). The new ones found in Ilara-mokin were
Hematochezia and blindness. They called mange (elewu) in Ilara-mokin and different to that of Ekiti State. 
New species of goat were found in Ilara-mokin (Grey, White and Black) compared to that of Ekiti state (Black, Brown) and that of sheep (Black) in llara-mokin and white in Ekiti state. Most of the goats were healthy probably because they feed on plantain and peels of beans while the sheep feed on grass and they were not healthy enough. Goats were more than sheep in llara-mokin. This could be due to the usefulness difference between these two ruminants. In llara-mokin, they practiced extensive and semi-intensive means of housing while intensive system of housing was very rare. This could be due to lack of finances within the small ruminant herders.

The ethno-veterinary practice discovered in this study can serve as an alternative medicine to orthodox medicine in rural areas of Nigeria (Lawal et al., 2010), because they are cheap and readily available within the community.

\section{Conclusions and Recommendation}

Base on the obtained results, it could be concluded that there should be biodiversity conservation of specie of flora and fauna that were going into extinction. It is therefore recommended that extension workers should educate the farmers more about the benefits of using ethno-veterinary practice to treat ruminant diseases.

\section{CONFLICT OF INTEREST}

The authors declare that they have no conflict of interest.

\section{ACKNOWLEDGEMENT}

Mr Bada Oluwafemi Alexander is acknowledged for his support during the study.

\section{REFERENCES}

Adeola, A. O., Adewole, S. O., Olofintoye, L. K. (2014). Studies on ethnoveterinary practice used to treat ruminant diseases in Ekiti State Nigeria. Research Journal of Agriculture and Environmental Management, 3(2), 362-645.
Khan, K., Rahman, I. U., Calixto, E. S., Ali, N., \& ljaz, F. (2019). Ethnoveterinary Therapeutic Practices and Conservation Status of the Medicinal Flora of Chamla Valley, Khyber Pakhtunkhwa, Pakistan. Frontiers in Veterinary Science, 6, 122.

Kolawole, O. D. (2007). Analysis of factors influencing rural employment promotion for community development in southern Nigeria. WIT Transactions on Ecology and the Environment, volume 102, 8 pages.

Kolawole, O. D., Ajayi, A. O., \& Adereti, S. D. (2000). Analysis of safety practices during the application of agrochemical and their implication for agricultural extension programme planning. Journal of School Health Education, 7(142), 92-103.

Kolawole, O. D., Okorie, V. O., Ogidiowa, M. T., \& Adeogun, M. A. (2007). Ethno-veterinary practices amongst small-holder farmers in Ekiti State, Nigeria. African Journal of Traditional, Complementary and Alternative Medicines, 4(4), 434-442.

Lawal, B. O., Ajayi, F. T., Oyegbami, A., \& Saka, J. O. (2010). Ethno veterinary practices of small ruminant livestock farmers in Southwestern Nigeria. Journal of Agriculture, Forestry and the Social Sciences, 8(2), 66-81.

McGaw, L. J., Van der Merwe, D., \& Eloff, J. (2007). In vitro anthelmintic, antibacterial and cytotoxic effects of extracts from plants used in South African ethnoveterinary medicine. The Veterinary Journal, 173(2), 366-372.

Obata, O. O., \& Aigbokhan, E. I. (2012). Ethnobotanical practices among the people of Oka-Akoko, Nigeria. Plant Archives, 12(2), 627-638.

Osho, I. B., \& Fasina, O. O. (2013). Small ruminants ownership pattern and level of veterinary consultation under traditional system of management in Ondo and Ekiti state of Nigeria. Russian Journal of Agricultural and Socio-Economic Sciences, 20(8), 3-10.

Rahmatullah, M., Mollik, A. H., Alam, J., Ahmmed, B., Jahan, F. I., Sintaha, M., Khaleque, H.N., Chowdhury, M. H., Noor, F. A., Rahman, S., \& Jahan, R. (2010). An ethnoveterinary survey of medicinal plants used by folk medicinal practitioners to treat cattle diseases in randomly selected areas of Bagerhat district, Bangladesh. American-Eurasian Journal of Sustainable Agriculture, 4(3), 386-397. 